\section{Genvarianter øker risikoen for psykisk sykdom}

\author{
Norske forskere har bidratt til oppdagelse av nye genvarianter som øker \\ risikoen for schizofreni og bipolar lidelse.
}

I de siste årene har man i store internasjonale samarbeidsprosjekter gjort en rekke nye funn innen psykiatrisk genetikk. Nå har norske forskere deltatt $\mathrm{i}$ en internasjonal studie som har lett etter genetiske årsaker til schizofreni og bipolar lidelse i større skala enn noen gang tidligere.

Forskerne påviste 11 enkeltnukleotidpolymorfismer, vanlige varianter $\mathrm{i}$ arvestoffet, med en sterk, robust assosiasjon med schizofreni og bipolar lidelse $(1,2)$. Seks av disse genene er ikke påvist tidligere. Funnene representerer et stort fremskritt i forståelsen av årsakene til disse to alvorlige psykiske sykdommene.

For schizofreni ble det identifisert sju genetiske områder, hvorav fem er nye (1p21.3, 2q32.3, 8p23.2, 8q21.3 og 10q24.32-q24.33) og to som er blitt påvist tidligere (6p21.32-p22.1 og 18q21.2). Det sterkeste nye funnet var i MIR137 (microRNA 137), som er en kjent regulator av nevronal utvikling. Tidligere funn av gener involvert $\mathrm{i}$ immunsystemet ble bekreftet. For bipolar lidelse ble sammenhengen med genet $A N K 3$ bekreftet, og to nye gener, $O D Z 4$ og $S Y N E 1$, påvist for første gang. Tre gener $C A C N A 1 C, A N K 3$ og ITIH3-ITIH4-regionen var assosiert med begge sykdommene, noe som styrker antakelsene om at det finnes felles biologisk sårbarhet for de to sykdommene, som har mange kliniske fellestrekk.

- Studiene styrker teorien om at immunologiske og nevronale utviklingsforstyrrelser spiller en rolle i patofysiologien ved schizofreni, og at regulering av cytoskjelettog kalsiumkanaler kan være involvert ved bipolar lidelse, sier professor Ole A. Andreassen ved Klinikk for psykisk helse og avhengighet, Oslo universitetssykehus, Ullevål.

- De påviste genetiske variantene er alle vanlige, og risikoen knyttet til den enkelte genvariant er forsvinnende liten - oddsratio var kun mellom 1,1 og 1,2. Dette styrker hypotesen om polygenetiske mekanismer, at det er flere hundre, kanskje tusen vanlige enkeltnukleotidpolymorfismer som bidrar til sykdomsutviklingen. I seg selv vil disse genvariantene være lite nyttige for diagnostikk, fordi de er så vanlige blant friske. Det kan derimot ha større betydning for forståelse av sykdomsmekanismene, sier Andreassen.

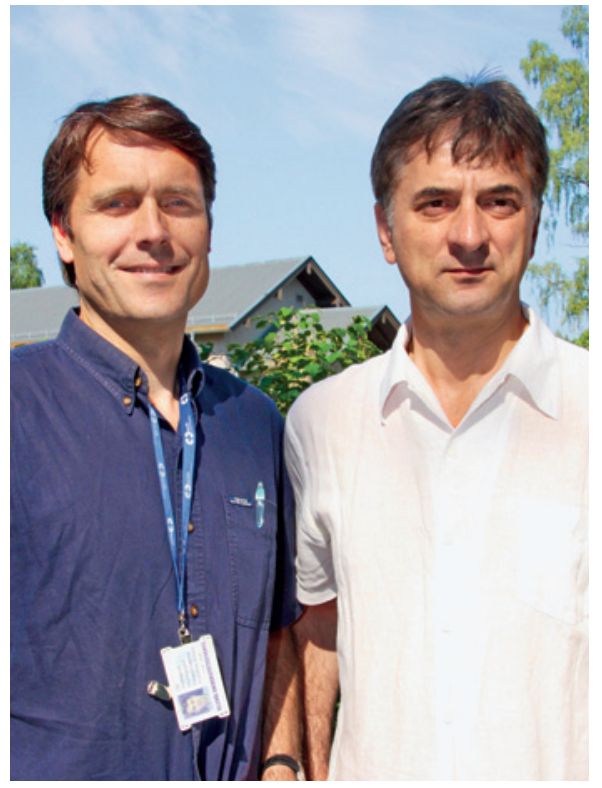

Ole A. Andreassen og Srdjan Djurovic, to av de norske artikkelforfatterne. Foto Alf Terje Bøhler

\section{Forskning om psykiatrisk genetikk}

Studiene utgår fra TOP-gruppen, som utgjør det største psykiatriske forskningsmiljøet i Norge. De aktuelle prosjektene har fra norsk side vært ledet av Ole A. Andreassen, med bidrag innen molekylærgenetiske analyser fra Srdjan Djurovic, biostatistiske analyser fra Morten Mattingsdal og pasientinklusjon fra Ingrid Melle, Ingrid Agartz og Gunnar Morken, som alle er medforfattere på artiklene.

\section{Erlend Hem}

erlend.hem@medisin.uio.no

Tidsskriftet

\section{Litteratur}

1. The Schizophrenia Psychiatric Genome-Wide Association Study (GWAS) Consortium. Genomewide association study identifies five new schizophrenia loci. Nat Genet 2011; 43: 969-76.

2. Psychiatric GWAS Consortium Bipolar Disorder Working Group. Large-scale genome-wide associ ation analysis of bipolar disorder identifies a new susceptibility locus near ODZ4. Nat Genet 2011. 43: 977-83.
Ordforklaringer

Enkeltnukleotidpolymorfisme lenkeltbasevariasjon, single nucleotide polymorphism, SNPJ er vanlige enkeltbasevarianter i genkoden, definert som en allel (genvariant) som finnes i minst $1 \%$ av befolkningen.

Genomvide assosiasjonsstudier: Pasient-kontroll-studier av genetiske risikofaktorer med bruk av genetiske markører spredt ut over alle kromosomene.

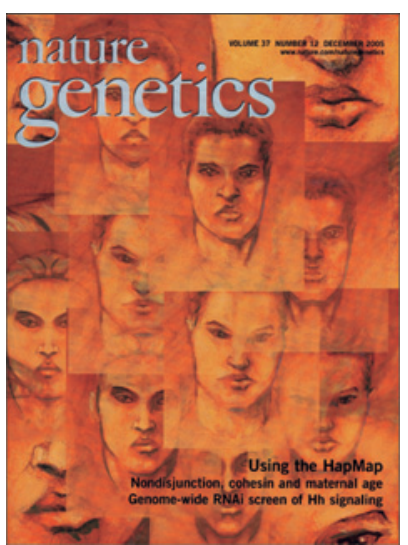

Artiklene ble publisert først på nett 18.9. 2011 i Nature Genetics (www.naturegenetics.com), som er det høyest rangerte tidsskrift innen genetikk 